\title{
Applied anatomy of the inferior external pudendal artery
}

\author{
Moacir Cymrot PhD Fellow, Lydia Masako Ferreira MD PhD \\ Plastic Surgery Division, Federal University of São Paulo, Escola Paulista de Medicina, \\ São Paulo, Brazil
}

\section{Cymrot, LM Ferreira. Applied anatomy of the inferior external pudendal artery. Can J Plast Surg 1999;7(2):86-90.}

The present study was conducted to assess the presence of the inferior external pudendal artery (IEPA), its diameter and course, and the cutaneous area nourished, and to support its use as an arterial pedicle in thigh flaps. Fifty thighs from 25 recent cadavers were dissected. IEPAs were found in $96 \%$ of the specimens, all arising from the femoral artery. Their average diameter was $1.4 \mathrm{~mm}$, and the distance from point of origin to line 'a' averaged $5.6 \mathrm{~cm}$. IEPAs appeared in front of the femoral vein in all cases and behind the great saphenous vein in $90 \%$ of cases. IEPAs ran medial and inferior courses, passing before the adductor magnus and pectineal muscles. Dye injection into the artery demonstrated that genital and anterosuperomedial areas of the thighs of the same side were nourished cutaneous territory. These anatomical characteristics of the IEPA support the raising of a septofasciocutaneous flap at the anterior superomedial aspect of the thigh.

Key Words: Inferior external pudendal artery; Thigh anatomy; Thigh flap

\section{Anatomie appliquée de l'artère honteuse externe inférieure}

RÉSUMÉ : Cette étude a été menée pour évaluer la présence de l'artère honteuse externe inférieure (AHEI), son diamètre et son trajet et la zone cutanée nourrie, et pour recommander son utilisation comme pédicule artériel dans les lambeaux de cuisse. Cinquante cuisses de 25 cadavres récents ont été disséquées. Les AHEI ont été trouvées dans $96 \%$ des spécimens, provenant toutes de l'artère fémorale. Leur diamètre moyen étaient de 1,4 mm et la distance du point d'origine à la ligne « a » était en moyenne de 5,6 cm. Les AHEI apparaissaient devant la veine fémorale dans tous les cas et derrière la veine saphène interne dans $90 \%$ des cas. Les AHEI parcouraient un trajet inférieur et interne, en passant devant le grand abducteur et les muscles pubiens. L'injection d'un colorant dans l'artère a révélé que les aires génitales et antéro-supéro-internes des cuisses du même côté étaient une région cutanée nourrie. Ces caractéristiques anatomiques des AHEI appuient le prélèvement de lambeaux septofasciocutanés à la face antéro-supéro-interne de la cuisse.

$\mathrm{L}$ oss of tissue of the genital region has made necessary various treatment approaches: skin grafts, thigh cutaneous flaps (1-5), thigh autonomized dermal flaps (6), fasciocutaneous flaps $(7,8)$ and musculofasciocutaneous flaps (9). In 1980 , the inclusion of the deep fascia was recommended in

Correspondence: Dr Moacir Cymrot, Plastic Surgery Division Surgery Department, Escola Paulista de Medicina, rua Napoleão de Barros, 715, $4^{\circ}$ andar, São Paulo, Vila Clementino - CEP 04024-002, Brazil. Telephone 55-11-576-4024, fax 55-11-571-6579, e-mail lydia.dcir@com.br dermal flaps (10), which were developed in the fasciocutaneous flaps of the medial region of the thigh $(11,12)$.

In the present study, the anatomy of the fasciocutaneous blood supply of the anteromedial aspect of the thigh was examined (especially that of the inferior external pudendal artery [IEPA]) to obtain data that could justify the use of a fasciocutaneous flap of the region based in this artery.

\section{LITERATURE REVIEW}

McGraw and Vasconez (10) recommended the inclusion of deep fascia in cutaneous flaps due to its extensive vascular network, which is of great importance for flap survival. 
Pontèn (13) described 'super-flap' of the leg, including skin, subcutaneous tissue and fascia, attaining the length to breadth ratio of 2.5 to 1 . Hirshowitz and Peretz (3) used bilateral superomedial thigh flaps for vulval and scrotal repair, suspecting that this was not a random blood supply. Har-Shai et al (14) studied the blood supply of the thigh superomedial flap and considered the superficial branch of the IEPA to be the most important and constant artery for flap blood supply. The territory nourished by the external pudendal artery (inferior), demonstrated through catheterization and luminal injection of opaque silicone, included the anteromedial aspect of the thigh and the labium majus or scrotum. The area of the anteromedial aspect of the thigh nourished by the superficial branch of the IEPA was $11 \times 8 \mathrm{~cm}$.

In 1987, Wang et al (12) demonstrated a suprafascial vascular plexus beneath the medial region of the thigh, giving off septofasciocutaneous branches. They suggested that the skin and fascia of that area of the thigh could be used independently from the gracilis muscle. In the literature reviewed, several studies were not concerned with the IEPA being the sole artery of a flap $(7,13,15-21,22-28)$.

\section{MATERIALS AND METHODS}

Twenty-five adult cadavers (50 thigh specimens), 13 male and 12 female, from the Service of Death Verification of the Surgery Techniques Department of the Escola Paulista de Medicina were dissected from June 1987 to November 1988. The following reference points were marked and thigh regions delimited to set up uniform patterns for the surgical approach to be used as fixed anatomical points of reference (Figure 1):

- A point half-way between the anterior superior iliac spine and the pubic tubercle of the same side, named point A; line ' $a$ ', transversal to the thigh and crossing the point A: line 'a' (superior limit of the thigh).

- Line 'b': articulary line of the knee (lower limit of the thigh).

- Midpoint of the articulary line of the knee: point B.

- A longitudinal line connecting points A and B: line ' $\mathrm{x}$ ', dividing the anterior region of the thigh into lateral and medial sides.

- Midpoint of line ' $x$ ': point $C$, determining line 'c', transversal to the thigh, dividing it into superior and inferior sides.

Specimens were dissected on both sides according to a standardized approach: palpation of the ipsilateral anterior superior iliac spine and pubic tubercle. Halfway between these points, skin and subcutaneous tissue was incised towards the internal tibial condyle up to the middle of the thigh. Subcutaneous fat was dissected with scissors. The femoral artery was carefully dissected from the inguinal arcade to approximately $15 \mathrm{~cm}$ downwards. The IEPA was recognized as being the most distal vessel relative to the superior external pudendal artery, arising medially from the femoral artery.

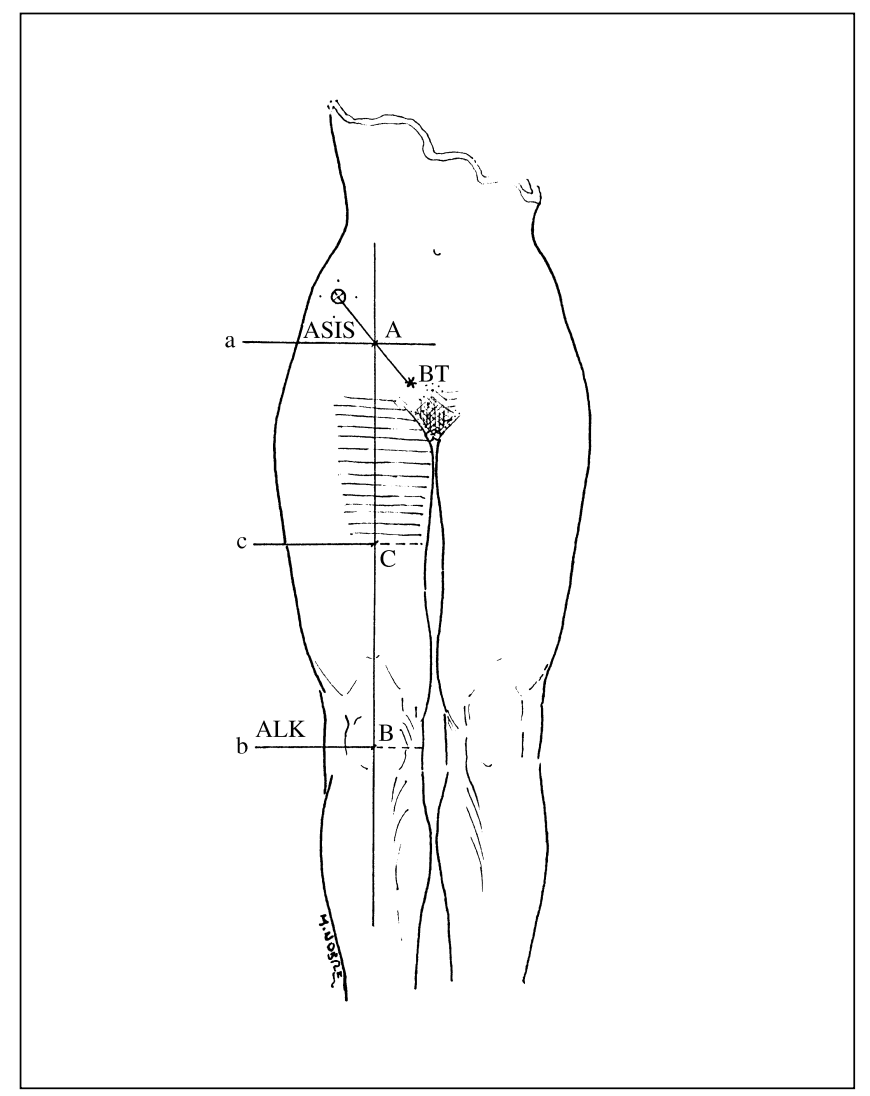

Figure 1) Outline of reference points of the thigh. ASIS Anterior superior iliac spine; BT Pubic tubercle; ALK Articular line of the knee

After dissection of the point of origin of the IEPA, the external diameter, the distance from its origin to line ' $a$ ', perpendicular to the thigh crossing the point halfway between the anterior superior iliac spine and the pubic tubercle of the same side, were measured with a pachymeter. Its course and relation to the femoral artery and the great saphenous vein were also studied. In 10 specimens, fasciocutaneous flaps were raised from the superomedial region of the thigh. During the raising of the flaps, musculocutaneous perforators had to be ligated in some cases. In other cases, they were included in the flap. IEPAs with sufficient luminal diameter were directly cannulized. With fine arteries, the catheter was introduced preferably into the femoral artery, connecting it proximally and distally to the IEPA. Initially, warm saline solution was injected to clear the lumen before a volume of 5 to $10 \mathrm{~mL}$ of bright green dye or blue nankeen ink was injected in the IEPA's lumen to colour the cutaneous area supplied by this artery. With this procedure, the dye was introduced without damaging the IEPA and the cutaneous area supplied by the IEPA could be visualized.

\section{RESULTS}

IEPAs were found in 24 cadavers (96\%). In all specimens, IEPAs were found to arise from the femoral arteries. Diameter ranged from $0.9 \mathrm{~mm}$ to $2.0 \mathrm{~mm}$ (average $1.4 \mathrm{~mm}$ ). The distance from IEPA origin to line ' $a$ ' (transversal to the thigh, 


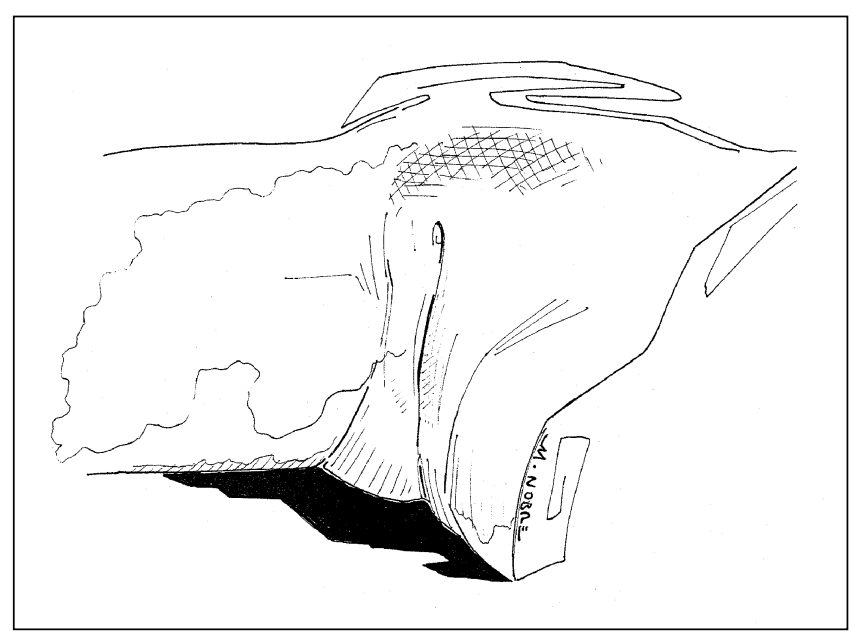

Figure 2) Schematic drawing of cutaneous area nourished by the inferior external pudendal artery

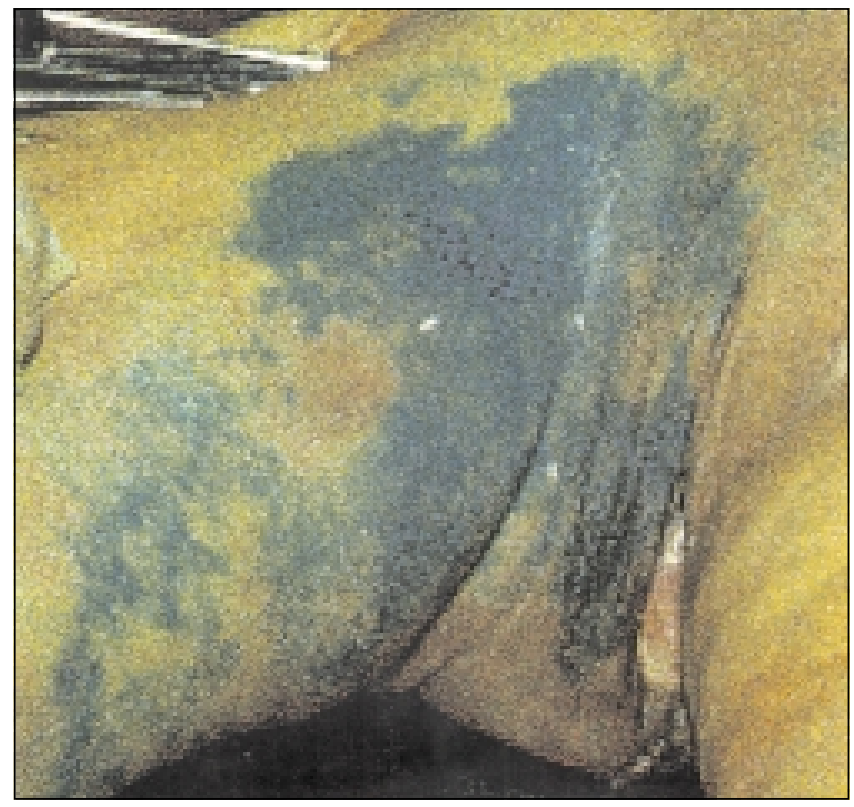

Figure 3) Female cadaver in horizontal position. Cutaneous area nourished by the inferior external pudendal artery demonstrated by dye injection in its lumen

crossing the point halfway between the anterior superior iliac spine and the pubic tubercle of the same side) ranged from $2 \mathrm{~cm}$ to $14 \mathrm{~cm}$ (average $5.6 \mathrm{~cm}$ ). The relation of the IEPA to the femoral vein was anterior in all specimens. The relation of the IEPA to the great saphenous vein was anterior to the great saphenous vein in only $9.5 \%$ of the specimens, being posterior or giving off posterior and anterior branches in the remaining specimens. The IEPA course was medial and inferior, before the adductor magnus and pectineus muscles. The genital area and the ipsilateral superomedial region of the thigh were the IEPA nourished cutaneous areas (Figures 2,3).

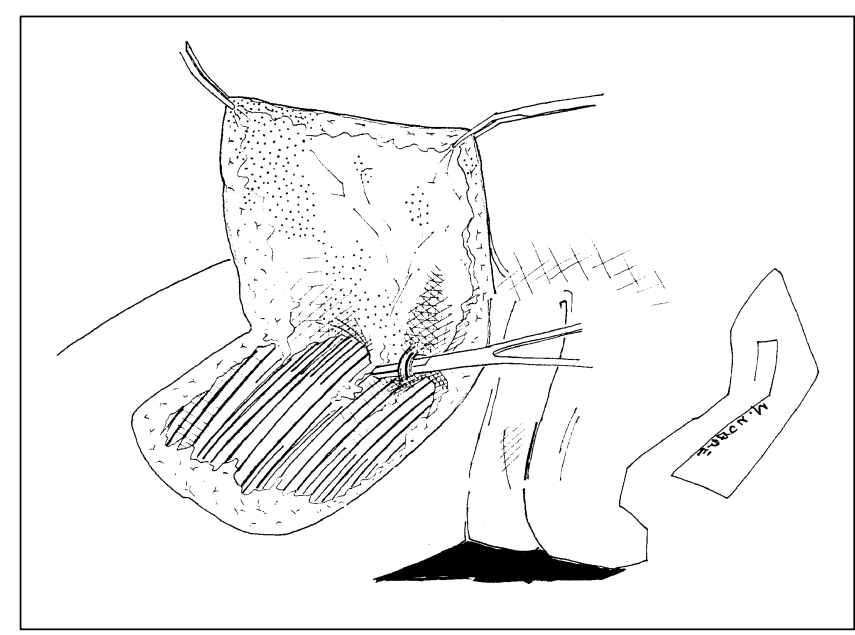

Figure 4) Schematic drawing of the inferior external pudendal artery

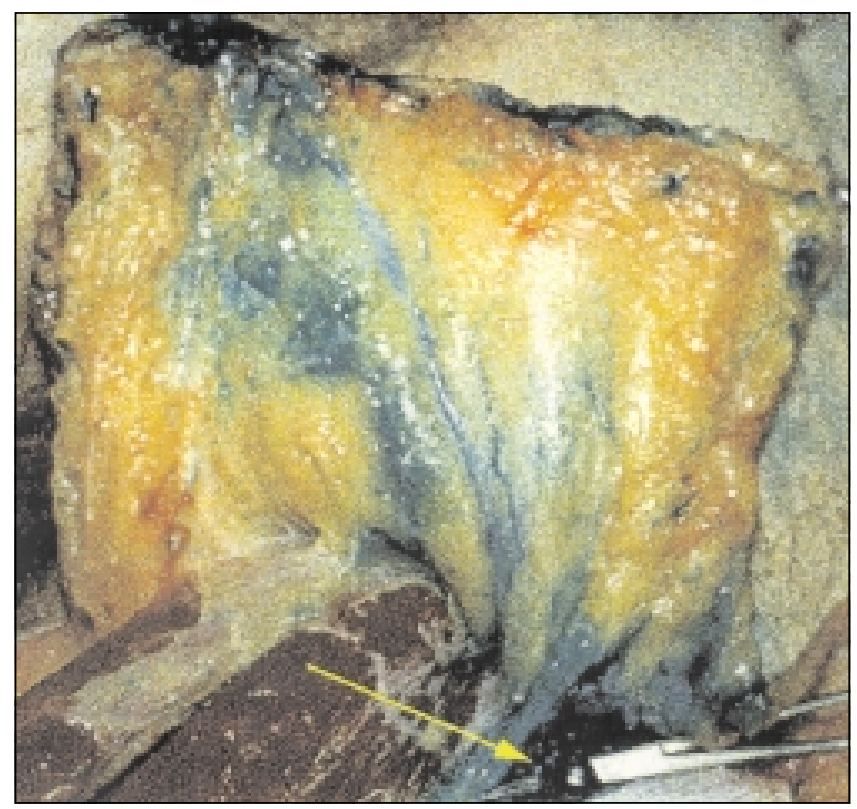

Figure 5) Medial and inferior course of the inferior external pudendal artery, anterior through to the muscles fascia (visualized by transparency) included in the raising of a superomedial flap of the anterior aspect of the thigh

\section{DISCUSSION}

Arterial branches originating from the femoral artery and running medially towards the genital region, namely the superior external pudendal artery and the IEPA, were observed during our dissections. The IEPA was considered more distally originated than the superior pudendal artery. A common trunk giving off the external pudendal arteries could not be found in any of the cadaver specimens examined; however, many authors have described a single external pudendal artery or superior and inferior pudendal arteries originating from a common trunk $(16-18,21,22,25,27,29)$. 


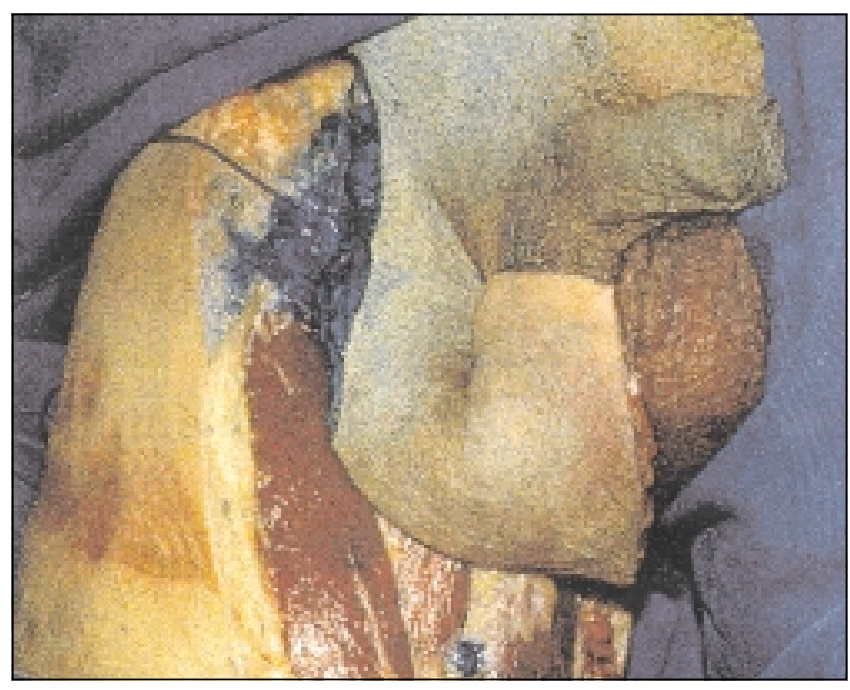

Figure 7) Septofasciocutaneous flap of the anterosuperomedial aspect of the right thigh suggested for loss of substance repair of the genital area

In the present study, IEPAs were found in $96 \%$ of the specimens examined but were not found on either side of one cadaver (4\%). Of the studies reviewed, La Falce (18) was the only author to quantify the frequency of this artery and obtained results that were similar to ours.

In the only cadaver lacking the IEPA, a branch $5 \mathrm{~mm}$ in diameter arising in the medial face of the femoral artery was found running under the pectineus muscle and giving off a tiny arterial branch $0.5 \mathrm{~mm}$ in diameter to the thigh skin. In the literature reviewed, no reference is made to an IEPA with such a diameter. Few of the studies reviewed assessed IEPA diameters $(14,18)$.

In the present study, IEPAs always arose from the femoral artery, which concurs with descriptions in the literature. Only Testut (25), Patten (19) and La Falce (18) accepted IEPAs as originating from the deep femoral artery.

IEPA distances to different reference points were mentioned in the literature review $(12,15,18,26)$. We selected as a reference the line ' $a$ ' obtained from easily recognizable fixed anatomical points. The distance of the IEPA's origin to the line 'a' ranged from 2.0 to $14.0 \mathrm{~cm}$.

In earlier studies $(14,16,20,22,25,27,28,30)$, the IEPA was found to be topographically situated in front of the femoral vein in $100 \%$ of the specimens dissected, confirming literature findings. Its eventual anterior and posterior positions are generally accepted $(21,23)$.

In $90.47 \%$ of the specimens examined, the IEPA was found posteriorly to the great saphenous vein or giving off anterior and posterior branches, confirming the literature findings $(20,22,25-28)$.

While studying the IEPA, staining techniques were used to determine the thigh cutaneous area nourished by this vessel. A subfascial system capable of nourishing a thigh superomedial flap or an arterial flap was sought. By including the fascia, as recommended by McGraw and Vasconez (10) and Pontèn (13), flap survival is more assured.

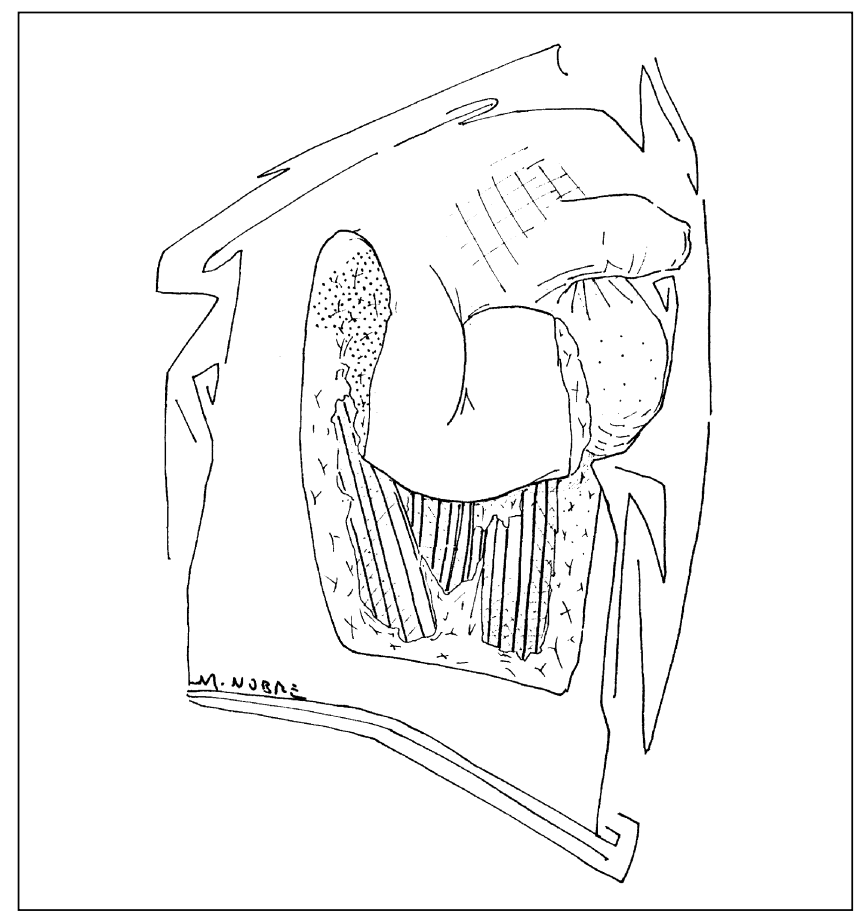

Figure 6) Schematic drawing of the anterosuperomedial aspect of the right thigh

The course and blood area supplied by the IEPA had already been studied by many authors. However, it was only after the discoveries of Hirshowitz et al (2) that more importance was given to the study of the area nourished by the IEPA and other arteries of the thigh with the purpose of raising flaps of that area $(2,3,7,12,14,28)$.

These findings suggest the possibility of raising a septofasciocutaneous flap of the anterosuperomedial flap aspect of the thigh with limits extending from the inguinal fold up to the middle of thigh (Figures 4,5).

\section{CONCLUSIONS}

The IEPA should be considered a normal anatomical structure because it has been found in $96 \%$ of the cadaver thighs studied. The IEPA arises from the femoral artery and was found to be topographically situated in front of the femoral vein in $100 \%$ of the specimens studied in which it was found. The IEPA was topographically shown to be predominantly posterior or with anterior and posterior branches to the great saphenous vein. Injections of dye into the IEPA identified the homolateral genital and thigh anterosuperomedial regions as the nourished cutaneous area. The findings of this study suggest the possibility of using a septal fasciocutaneous flap of the region pedicled at the IEPA, as shown in Figures 6 and 7 .

\section{REFERENCES}

1. Douglas B. One-stage reconstruction for traumatic denudation of penis and scrotum. Ann Surg 1951;133:889.

2. Hirshowitz B, Moscona R, Kaufman T, Pnini A. One-stage reconstruction of the scrotum following Fournier's syndrome using a probable arterial flap. Plast Reconstr Surg 1980;66:608-12. 
3. Hirshowtiz B, Peretz BA. Bilateral superomedial thigh flaps for primary reconstruction of scrotum and vulva. Ann Plast Surg 1982;8:390-6.

4. Kaplan I. A rapid method for constructing a funcional sensitive penis. Br J Plast Surg 1971;24:342-4.

5. Tiwari IN, Seth HP, Mehdiratta KS. Reconstrution of the scrotum by thigh flaps. Plast Reconstr Surg 1980;66:605-7.

6. Balakrishanan C. Scrotal avulsion: a new technique of reconstruction by split skin graft. Br J Plast Surg 1956;9:38.

7. Casey RP, Darsonval V, Simons G, Greco JM. Reparation par lambeau cutanéo-aponévrotique de cuisse d'une importante avulsion tégumentaire périnéo-scrotale: a propos d'un cas. Ann Chir Plast Esthet 1985;30:175-80.

8. Matti BA, Crawford BS. A supero-medial thigh flap for urethral reconstruction in epispadias and hypospadias. Br J Plast Surg 1985;38:46-50.

9. Ramos RR, Andrews JM, Ferreira LM. A gracillis myocutaneous flap for reconstrution of the scrotum. Br J Plast Surg 1984;37:171-4.

10. McGraw JB, Vasconez LO. Musculocutaneous flaps: principles. Clin Plast Surg 1980;7:9-13.

11. Morton KE, Davies D, Dewhurst J. The use of the fasciocutaneous flap in vaginal reconstrution. Br J Obstet Gynaecol 1986;93:970-3.

12. Wang TN, Whetzel T, Mathes SJ, Vasconez LO. A fasciocutaneous flap for vaginal and perineal reconstruction. Plast Reconstr Surg 1987;80:95-103.

13. Pontèn B. The fasciocutaneous flap: its use in soft tissue defects of the lower leg. Br J Plast Surg 1981;34:215-20.

14. Har-Shai Y, Hirshowitz B, Marcovich A, Eliachar I, Peretz BA. Blood supply and innervation of the supermedial thigh flap employed in one-stage reconstruction of the scrotum and vulva - an anatomical study. Ann Plast Surg 1984;13:504-10.

15. Dubreuil-Chambardel L. Variations des artères du pelvis et du membre infèrieur. In: Dubreuil-Chambardel L, ed. Traité des variations du système artèriel, 1. Paris: Masson,1925:138-63.

16. Falcone C. Arterie della grande circolazione. Aorta. In: Falcone C. Trattado di anatomia umana. Milano: Villadi, 1931:523-637.
17. Kopsch FV. Lehrbuch und atlas der anatomie des menschen, 14th edn. Leipzig: Thieme, 1933:195-457.

18. La Falce OL. Contribuição para o estudo anatômico das artérias pudendas externas no homem. Escola Paulista de Medicina, São Paulo, 1986. (Masters thesis)

19. Patten BM. The cardiovascular system. In: Schaffer JP, 10th edn. Morris Human Anatomy: A Complete Systematic Treatise. Philadelphia: Blakiston, 1942:582-785.

20. Pereira-Guimarães J. Tratado de anatomia descriptiva. Rio de Janeiro: H. Laermmert, 1894:331-634.

21. Poirier P. Angèiologie: coeur et artères. In: Poirier P, Charpy A. Traité de anatomie humaine. 2nd edn. Paris: Masson, 1902:547-850.

22. Sappey C. Angiologie. In: Sappey C. Traité d'anatomie descriptive, 3rd edn. Paris: Adrien Delahave, 1876:461-896.

23. Spalteholz W. Atlas de anatomia humana, 10th edn. Barcelona: Labor, 1976.

24. Tandler J. Tratado de anatomia sistematica. Barcelona: Salvat, 1929.

25. Testut L. Artères. In: Traité d'anatomie humaine. Paris: Gaston Doin, 1929:161-403.

26. Testut L, Jacob O Miembros. In: Testut L, Jacob O. Tratado di anatomia topográfica con aplicaciones médicoquirurgicas, 7th edn. Barcelona: Salvat, 1947:911-1186.

27. Versari R. Rami terminal dell'aorta. In: Bertelli D,Versari R. Trattado di anatomia umana, 2nd edn. Milano: Vallardi, 1932:488-534.

28. Wolf-Heidegger G. Iunctural ossium. In: Wolf-Heidegger G. Atlas de anatomia humana, 2nd edn. Rio de Janeiro: Guanabara Koogan, 1974:97-127.

29. d'Alessio E, Rossi F, d'Alessio R. Reconstrution in traumatic avulsion of penile and scrotal skin. Ann Plast Surg 1982;9:120-4.

30. Chiarugi G. Artéria femorale, artéria poplítea e loro rami. In: Chiarugi G. Instituzioni di anatomia dell'uomo, 4th edn. Milano: Vallardi, 1936:505-28. 